\title{
(1) Marriage, Childbearing and Single Motherhood: Trends in Attitudes and Behaviour in Czechia and Slovakia from 1991 to $2017^{1}$
}

\author{
Beatrice-Elena Chromková Manea, Ladislav Rabušic
}

\begin{abstract}
Given the intensive political and economic transformation process, followed by demographic changes that has characterized the Czech Republic and Slovakia since 1989, we examine the variation in personal values and attitudes towards marriage, childbearing and single motherhood in these two countries. The main goal is to examine if the trends in values concerning marriage, childbearing and single motherhood observed between 1991 and 2017 were accompanied by similar demographic changes. Data from four waves of the European Value Study (EVS) are used, together with official vital demographic statistics. Our analysis shows that the correspondence between attitudinal survey-micro-data and aggregated (statistical) macro data is quite considerable and that there is a link/association between attitudes and behaviours.
\end{abstract}

KEY WORDS European Values Study, attitudes, childbearing, fertility, marriage, out-of-wedlock births

\section{Introduction}

One of the most visible features in Czech and Slovak societies after the radical political changes "from socialism to capitalism" in 1989 (labelled as the Velvet Revolution) have been "new" trends in demographic behaviour characterized by a decrease in the number of marriages, an increase in the age at first marriage, the postponement of childbearing, a decrease in the number of children people have, and/or an increase in the share of people living in consensual unions (instead of marriage). These trends, which have been observed already for more than half a century (since the 1960s) in Western countries, have been summed up under the term Second Demographic Transition - SDT (van de Kaa 1997, 2001; Lesthaeghe 1983, 1995). The key element of this phenomenon - in the view of many scholars - is a substantial value change (see e.g. McDonald 2006; Inglehart and Welzel 2005; Cleland 1985; van de Kaa 1997, 2001; Lesthaeghe 1983, 1995; Inglehart 1997;

Sociální studia / Social Studies 2/2019. S. 25-50. ISSN 1214-813X.

$1 \quad$ Funding for this research was provided by the Czech Science Foundation - project number GA1702022S “Hodnotové změny v České republice z evropské a světové perspektivy (Evropský výzkum hodnot/Světový výzkum hodnot 1991-2017).” We acknowledge suggestions by anonymous reviewers. The final version of the paper is ours, though, and the reviewers bear no responsibility for any errors and mistakes. 
Sobotka 2008; Sobotka et al. 2008). The (evolutionary) argument is that socio-economic modernization leads to human development (Inglehart and Welzel 2005), which allows people to make independent choices in concordance with their needs for self-realization and freedom of action. This scenario leads to a humanistic culture that shapes new values concerning - among others - sexual norms, gender roles, family values and work aspirations, which may have an impact on demographic behaviour.

In Czechia and Slovakia, after 1989, as mentioned above, the old "socialist" demographic regimes have been replaced relatively quickly by the regime of the SDT. Because values have been regarded as the trigger activating new demographic behaviour in Western countries and thus perceived as being in accordance with behaviour, the compelling question is whether such an interplay of values and behaviour can also be found in countries in which political, economic and social changes have been quite rapid. In other words, our research question is whether in Czechia and Slovakia, where the current demographic situation is similar to that in Western countries, demographic development is accompanied by concomitant value change. We will focus on marriage, childbearing and single motherhood both from the perspective of value change and behaviour, by use of survey and macro demographic data.

\section{Theoretical framework}

From a sociological point of view, our research question is based on a (valid) assumption because, by definition, values, as principles or standards of life, provide general guidelines for behaviour: they help us assess what is right and wrong; they lay out our priorities and influence our choices among various courses of action. In demographic analyses, however, values, as a trigger for conduct, have been not been regarded as a relevant analytical factor for rather a long time. The onset of such neglect was established by Davis Kingsley 55 years ago, who in his macro-level analysis of change in modern demographic history, wrote that the explanation of change in demographic behaviour cannot be explained as "a function of a 'traditional' or 'value system" (Kingsley 1963:354). He even disregarded values - in his view, values could not be used as an explanation because they were part of behaviour itself. Later, however, values came to be considered as a useful explanatory factor. In the 1980s, the World Fertility Survey, a massive exploratory study of reproductive behaviour and reproductive health, concluded:

Taken en masse, the results are more consistent with an ideational theory of change based on the spread of new aspirations or new attitudes towards family formation or birth control, than with a structural theory, which emphasized changes in the economic roles of family units or of children, (Cleland 1985:243)

In 1999, the edited monograph Dynamics of Values in Fertility Change was published with the aim to situate values in their rightful place in the research on fertility. In the book, relationships between values and behaviour (to be precise, mainly fertility) were studied by a number of prominent scholars. Their findings, however, were mixed: some found that values are variables that respond to political, economic and demographic contexts and they are re-constructed as these contexts change (Goldscheider 1999: 327). Some argued that changes 
in (fertility-related) values tend to lag behind changes in fertility behaviour (Retherford et al. 1999). Some even suggested that changes in behaviour precede changes in attitudes (Rindfuss et al. 1999). Uhlenberg, who reviewed the monograph, concluded that "...given a lack of consensus by the contributors to this volume regarding the place of values in fertility research, it appears that the question of its 'rightful place' is still open" (Uhlenberg 2000: 400).

Values are also taken into consideration by authors who attach importance to economic factors in explaining, for instance, low levels of fertility in developed countries (e.g. Easterlin 1980; Becker 1991). Apart from macro-level approaches, micro-economic models (e.g. Becker's New Home Economics or Easterlin's model) have been developed to incorporate the decision-making processes of individuals. The assumption here is that an individual (or a couple) makes rational choices, which lead to the maximization of utility (i.e. level of satisfaction). In doing so, they will take into account the economic and social conditions that frame their everyday life and will prefer - based on their values - some actions over others.

In this paper, we do not aim to resolve the question regarding relationships between values and behaviour. As sociologists, we assume that if human actions are intentional (and we believe that they are), then all human behaviour is circumscribed by values. Values, however, are constructs, latent entities of our personalities and, as such, they are not open to direct observation and measurement. They can be inferred only indirectly based on people's behaviour, or assumed from recorded answers to questions about people's values. As people often do not know what their values are, various indicators must be used to measure their attitudes (which are deemed to be verbalized values) and/or preferences. We aim to find out whether values concerning marriage, children and single motherhood correspond to actual demographic behaviour. We can do so because we have data on both behaviour - i.e. relevant aggregate demographic data from national statistics - as well as attitudes - i.e. individual data collected through surveys.

The main goal of our paper is to examine if the trends in attitudes (values) observed since the beginning of the 1990 s, i.e. after transformational political and economic changes, until the present time have been accompanied by similar demographic changes. Our analysis covers the period between 1991 and 2017 (for an explanation, see below) and the research was conducted as a comparative study of two countries - Czechia and Slovakia.

Why these two countries? Czechia and Slovakia came into existence as one state in 1918 named the Czechoslovak Republic (Czechoslovakia) and it consisted of two primary nations and populations - Czechs (living in the western part of the country) and Slovaks (living in the eastern zone). Even though both nations speak very similar languages and the interaction among the people has been intensive, ${ }^{2}$ and, from an economic point of view, Czechoslovakia was among the ten most developed countries of the world during the 1920s and 1930s (Deyl 1985 ) - the two populations were culturally and economically slightly different. Czechia

2 For instance, intercultural marriages, i.e. marriages between people of different ethnicities and geographic regions, have been quite common; TV and radio were broadcast in both the Czech and Slovak languages all over the country; and the Czechoslovak government, including the National Assembly, consisted of a mixture of Czech and Slovak politicians. 
(the Czech Republic) was more industrialized and its inhabitants enjoyed higher standards of living, were less religious and ideologically more liberal (demographic behaviour included). ${ }^{3}$ Slovakia was more agrarian, more religious and more traditional (also demographically). These slight differences endured for forty years despite massive attempts by the communist regime ${ }^{4}$ to homogenize the living conditions of Czechoslovaks and to create an all-encompassing "socialist way of life." After the fall of communism in 1989, both countries experienced rapid socio-economic development and - by 2017 - they are among the group of highly developed, even post-industrial, countries. ${ }^{5}$ In 1993, the two countries decided to go their separate ways and after the "Velvet Divorce," two new independent states were established: the Czech Republic (Czechia) and the Slovak Republic (Slovakia). The second aim of the paper is thus to see to what extent the independent existence of the two countries has led to convergence or divergence of values and demographics. An important remark must be made from the outset: we shall not test any hypotheses; our analysis is exploratory.

\section{Country demographic context - Czechia and Slovakia}

As we have noted, Czechs and Slovaks have changed their demographic behaviour quite rapidly since the political and economic changes initiated in 1989. While during the 1970s and the 1980s demographic indicators were different from those recorded in Western countries, they started to converge during the 1990s. The following tables (see Table 1a and $1 \mathrm{~b}$ ) illustrate the development of the main demographic indicators related to our topic.

In the 1980s, and still in 1990, marriage was a universal model for Czech and Slovak men and women, as shown by the data on the total first marriage rate, ${ }^{6}$ as well as the age at first marriage. They indicate that more or less all individuals (about $90 \%$ of men and $91-96 \%$ of women) were married at least once, and they did so rather young. Naturally, the share of out-of-wedlock births was low. This stood in sharp contrast with the Western model, in which the onset of unmarried cohabitation at the end of the 1960s and its gradual social acceptance ${ }^{7}$ decreased the marriage rate, increased marriage age and also increased the proportion of births outside of marriage.

3 The famous "Hajnal's line" mirrors more or less the borders between Czechia and Slovakia. The Hajnal line links Saint Petersburg, Russia, and Trieste, Italy, and divides Europe into two areas characterized by different levels of nuptiality.

4 The regime was installed by coup d'état in 1948 when the Communist Party seized political power.

5 The indicators of post-industrialism are usually regarded as follows: (i) the structure of the labour force - (\%) in the main sectors of the economy (agriculture, industry, services); (ii) GNI per capita; (iii) percentage of female employment; (iv) the share of people (aged 15-64) with tertiary education; (v) spending on research and development as a percentage of GDP; (vi) life expectancy; and (vii) the Human Development Index and the Gender Inequality Index.

6 The total first marriage rate is defined as the sum of the age-sex specific first marriage rates. It represents the proportion of women or men who would eventually marry, if they were subject through their lifetime to the age-sex specific first marriage rates of a given period.

7 Societies have started to accept different forms and models of alternatives to marriage. Marriage has become deinstitutionalized. 
Table 1a: Main demographic indicators in the Czech Republic, 1980-2017

\begin{tabular}{|l|r|r|r|r|c|}
\hline & $\mathbf{1 9 8 0}$ & $\mathbf{1 9 9 0}$ & $\mathbf{2 0 0 0}$ & $\mathbf{2 0 1 0}$ & $\mathbf{2 0 1 7}$ \\
\hline Mean age at first marriage & & & & & \\
\hline Men & 24.9 & 24.0 & 28.9 & 32.2 & 32.2 \\
\hline Women & 21.7 & 21.4 & 26.5 & 29.4 & 29.8 \\
\hline Total First Marriage Rate (\%) & & & & & \\
\hline$\quad$ Men & 89.7 & 91.1 & 69.5 & 54.9 & 57.6 \\
\hline Women & 96.9 & 96.2 & 74.4 & 61.6 & 65.4 \\
\hline Mean age at first birth (women) & 22.4 & 22.5 & 24.9 & 27.6 & 28.2 \\
\hline Total fertility rate & 2.10 & 1.89 & 1.14 & 1.49 & 1.69 \\
\hline Percentage of live births outside of marriage & 5.6 & 8.6 & 21.8 & 40.3 & 49.0 \\
\hline
\end{tabular}

Note: Data from Czech Statistical Office (ČSÚ).

Table 1b: Main demographic indicators in Slovakia, 1980-2017

\begin{tabular}{|l|r|r|r|c|c|}
\hline & $\mathbf{1 9 8 0}$ & $\mathbf{1 9 9 0}$ & $\mathbf{2 0 0 0}$ & $\mathbf{2 0 1 0}$ & $\mathbf{2 0 1 7}$ \\
\hline Mean age at first marriage & & & & & \\
\hline Men & 24.0 & 23.5 & 26.4 & 29.7 & 30.6 \\
\hline Women & 21.7 & 21.1 & 23.9 & 27.0 & 28.1 \\
\hline Total First Marriage Rate (\%) & & & & & \\
\hline$\quad$ Men & 81.4 & 88.0 & 46.1 & 47.6 & 65.0 \\
\hline Women & 87.1 & 94.0 & 52.0 & 51.7 & 66.7 \\
\hline Mean age at first birth (women) & 22.7 & 22.6 & 23.9 & 27.3 & 27.8 \\
\hline Total fertility rate & 2.31 & 2.09 & 1.30 & 1.42 & 1.48 \\
\hline Percentage of live births outside of marriage & 5.6 & 7.6 & 18.3 & 33.0 & 40.2 \\
\hline
\end{tabular}

Note: Data from www.infostat.sk, Verejná databáza DATAcube, Eurostat, Branislav ŠPROCHA, Luděk ŠÍDLO: Storočie zmien sobášnosti a rozvodovosti v Českej republike a v Slovenskej republike.

During the 1990s, as democratic institutions became established in Czechia and Slovakia and contact with Western cultures was intensive, an overall climate of freedom prevailed and demographic behaviour shifted. Marriages started to be postponed to later ages, unmarried cohabitation increased and a rapid decline in marriages occurred. The universality of marriage virtually disappeared. Corresponding to these changes, there was also a dramatic decrease in fertility (see Czech and Slovak total fertility rates in 2000 in Tables 1a and 1b), partially due to a delay in first births (indicated by the female mean age at first marriage in Tables $1 \mathrm{a}$ and $1 \mathrm{~b}$ ). Fertility rates were among the lowest in the world by 2000 , not only in Czechia and Slovakia, but also in other Central and Eastern European countries (Thornton and Philipov 2009).

A glance at the demographic data in Tables $1 \mathrm{a}$ and $1 \mathrm{~b}$ reveals that demographic behaviour concerning marriage, the family and fertility changed enormously in Czechia 
and Slovakia during the 1990s and especially during the first decade of the 2000s. Has such change been accompanied by a change in value preferences? We answer this question in the following sections.

\section{Method and data}

As the purpose of this paper is to examine whether there is a relationship between attitudes towards marriage, having children and single motherhood on the one hand and demographic behaviour on the other, we shall use two sets of data: survey data and official demographic statistics. The source for our attitudinal data is the European Values Study (EVS). It is a large international comparative longitudinal survey measuring indicators of value change/consistency in Europe ${ }^{8}$ and has been carried out in many European countries four times to date: in 1991, 1999, 2008 and 2017, Czechia and Slovakia included. The EVS covers a wide variety of topics in the survey by means of a standardized questionnaire, ${ }^{9}$ including marriage, the family and divorce. A random probability sample scheme is used in order to collect the data, representing the population aged 18 and older. ${ }^{10}$ Table 2 provides information on the sample sizes and the method of data collection used in both countries in all four waves, along with response rates.

Table 2: Sampling scheme EVS 1991-2017

\begin{tabular}{|l|l|c|c|c|}
\hline \multirow{4}{*}{ Czechia } & Year & Sample size & Method of data collection & Response rate \\
\cline { 2 - 5 } & 1991 & 2109 & face-to-face PAPI & $67 \%$ \\
\cline { 2 - 5 } & 1999 & 1908 & face-to-face PAPI & $61 \%$ \\
\cline { 2 - 5 } & 2008 & 1821 & face-to-face PAPI & $62 \%$ \\
\cline { 2 - 5 } & 2017 & 1812 & face-to-face PAPI and CAPI & $62 \%$ \\
\hline \multirow{6}{*}{ Slovakia } & Total & 7650 & & $67 \%$ \\
\cline { 2 - 5 } & 1991 & 1137 & face-to-face PAPI & $62 \%$ \\
\cline { 2 - 5 } & 1999 & 1327 & face-to-face PAPI & $60 \%$ \\
\cline { 2 - 5 } & 2008 & 1509 & face-to-face CAPI & $61 \%$ \\
\cline { 2 - 5 } & 2017 & 1435 & & \\
\hline
\end{tabular}

Source: our own EVS datasets 1991-2017 CZ and SK.

$8 \quad$ For further details, see http://www.europeanvaluesstudy.eu/.

9 The methodology of data collection and questionnaire formation are quite strict and standardized both at the international and national levels so that the comparability both among countries and between waves is ensured.

10 As it occurs in surveys, despite our adherence to sampling procedures designed to ensure representativeness, the datasets in all waves were slightly biased; accordingly, we applied weighting schemes. We used post-stratification weights, created based on the structure of the population in Czechia and Slovakia with respect to age, gender, education and region. The weighting of the samples was also undertaken in other participating countries according to the centrally determined EVS methodological rules. 
For the purposes of our analysis, we work with the following questionnaire items/questions:

a. Attitudes towards marriage: Do you agree or disagree with the following statement: Marriage is an outdated institution? Answer options: 1 - Agree, 2 - Disagree

b. Attitudes towards having children: Do you think a woman has to have children in order to be fulfilled or is this not necessary? Answer options: 1 - She needs children, 2 - It is not necessary

c. Attitudes towards single motherhood: If a woman wants to have a child, but she wants to be a single parent and live without a man, do you approve or disapprove? Answer options: 1 - I approve, 2 - I disapprove, 3 - It depends on the situation

The sources of demographic data consist of official demographic statistics from the Czech and Slovak Statistical Offices, covering the period between 1991 and 2017. ${ }^{11}$ Demographic data are collected each year by national statistical offices, which allow us to observe the demographic trends over time. Indicators of personal values and attitudes do not need to be recorded regularly every year because - usually - human values do not change very rapidly. We believe, therefore, that the four waves of EVS measurement - 1991, 1999, 2008 and 2017 - create a sufficient time series, which enables us to illustrate the longitudinal aspect of value change in both countries and to compare them with the demographic trends between 1991 and 2017 in a meaningful way. ${ }^{12}$

In the analysis, descriptive statistics are used for the attitude questions. The analysis is run separately for the whole population and by the main socio-demographic characteristics (e.g., age groups, gender and marital status). Then, the two variables - attitudinal and demographic indicators - are compared side-by-side in order to reveal the possible relation between them. Given the inconclusive previous analyses on the relationship between attitudes and demographic behaviour, we make no assumption about the nature of the relationship between the variables included in the analysis - which of the two variables is dependent and which is independent. Our analysis is, generally speaking, strictly explorative.

\section{Results}

Do attitudes towards marriage as an outdated institution go hand-in-hand with the demographic indicators on marriage?

Marriage has traditionally been a crucial event in the lives of young people because it has been a precursor of children and the family. In many European countries, this is however no longer the case because quite a number of (young) people have children without being married

11 Such a time span is used to provide correspondence to the period for which we have attitudinal data.

12 Unfortunately, there are no relevant attitudinal data for the period before 1989, i.e. before the collapse of the communism. Surveys and public opinion polls were seldom carried out in communist times and quite often, the results were not published - they were classified, and only available for the use of Communist Party leaders. 
(cf. Sobotka et al. 2003; Surkyn and Lesthaeghe 2004). The important question is, therefore, whether marriage remains an attractive institution for the Czech and Slovak populations in light of a permissive climate that allows people to live with a partner in the same household without being legally married and - even more - to have children in such unions.

The European Values Study contains questions concerning the institutions of marriage and cohabitation and their attractiveness. As far as marriage is concerned, EVS research operationalizes such attitudes through the question of whether respondents think marriage is an outdated institution. We look first at the attitudes towards marriage in the whole sample, and then to their distributions by gender, age groups and marital status (married, divorced and never married). The distribution of answers in the sample and for male and female respondents separately is shown in Figure 1.

Figure 1: Agreement with the statement on marriage as an outdated institution in Czechia and Slovakia, 1991-2017 population $18+(\%)$
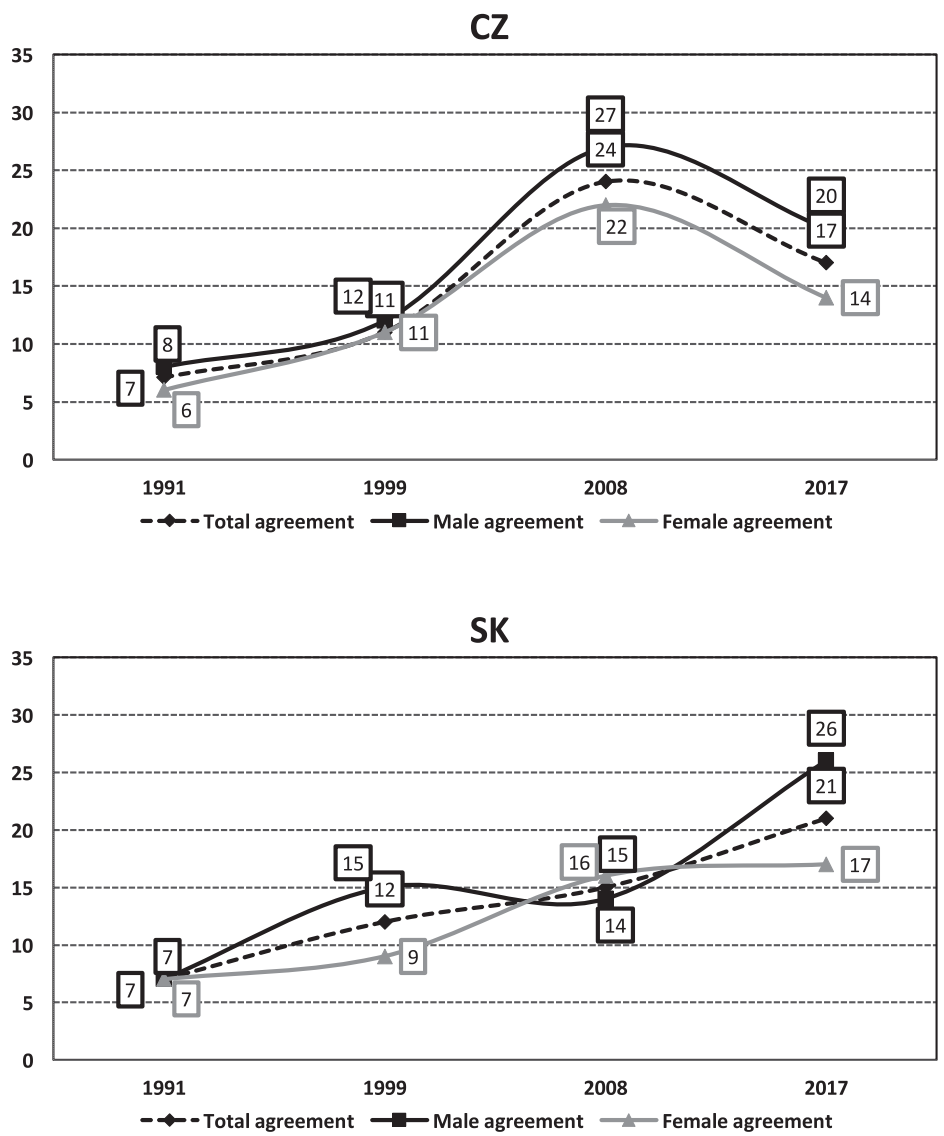

Source: own calculations using EVS datasets 1991-2017 CZ and SK. 
The development of opinion on marriage as an institution exhibits different trajectories in Czechia and Slovakia even though they started from the same base. In 1991, only 7\% of the sample both in Czechia and in Slovakia agreed that marriage is an outdated institution. By 2017, the share of agreeing respondents increased to $17 \%$ in Czechia and 21\% in Slovakia. Although the four-percentage-point difference is statistically significant $(p=0.05)$, it does not mean much in reality; ${ }^{13}$ thus, we can state that the two populations do not differ in their attitude towards the obsoleteness of marriage.

They differ in the trajectory, however. In Slovakia, there was a more or less gradual (but almost linear) increase between 1991 and 2017 while in Czechia, there was a steep increase between 1991 and 2008, followed by a sharp drop. There is no simple way to interpret these trends. The fact is that a minority of respondents in both countries regards marriage as an outdated institution. Taking into account the fact that in 2017, the corresponding numbers were similar for Denmark and Sweden, i.e. the countries regarded to be leaders in the Second Demographic Transition, ${ }^{14}$ namely $17 \%$ and $26 \%$ respectively, we can speculate that marriage as a form of relationship between a man and a woman remains an important cultural (and traditional) aspect in people's minds, which is not refuted despite the fact that many people prefer to live in other forms of arrangement - i.e. unmarried cohabitation, living-aparttogether (LAT) or remaining single.

As far as gender differences are concerned, there were de facto no differences between male and female respondents in Czechia and the trajectory of their trend was very similar. Not so in Slovakia, however. Male-female differences were a bit higher (in 1999 and 2017) but the trajectories exhibited an interesting negative mirror-like reflection. They started at the same share of agreement (7\%) but ended up in a nine-percentage point difference in 2017. And, as in Czechia, there were more men than women who agreed with the statement in 2017 (26\% and $17 \%$, respectively). These results were surprising to a certain extent because we assumed - taking into account the modernization level of both countries - that more Czechs than Slovaks would agree with the statement about the obsoleteness of marriage.

Table 3 presents the agreement rates by age group and marital status. The distinction by these two socio-demographic characteristics is important because it is alleged that the older a person is, the more traditional the attitude towards marriage. In addition, those who experience divorce or are married have different attitudes than those who have never been married.

When we look at the distribution of answers by age group, we can see that the assumption about the more conservative attitude of older age groups is confirmed: in all waves and in both countries the older respondents are, the less they think that marriage is an outdated institution. Moreover, respondents aged $60+$ years maintained a more or less unchanged attitude between 1991 and 2017 (especially in Slovakia) while the share among the youngest increased in a linear fashion from 1991 to 2017 (7\% and 36\%, respectively).

13 The samples are large and thus, even small differences are statistically significant. In terms of factual difference, only more than $10 \%$ indicates that in reality something differs.

14 The important aspect of the Second Demographic Transition in van de Kaa's (1987) perception is value change. 
In Czechia, we see a similar linear increase until 2008, interrupted, however, by a sudden drop in 2017 (from 43\% to 28\%). The reasons for this drop remain unclear to us. Therefore, in 2017, there were more young Slovaks than Czechs who agreed with the statement, which is a surprising result. Nevertheless, the overall results indicate that even among the young, the majority of respondents ( $72 \%$ in Czechia and $64 \%$ in Slovakia) do not regard marriage as something obsolete.

The distribution of answers by marital status (see Table 3) brings a compelling picture. We compare those who are married (for whom we expect the lowest levels of agreement), divorced (who should express low agreement, but not as low as those never married) and never married (for whom the agreement rate should be the highest). This assumption is more or less confirmed: in all the years, it was the married group who expressed the lowest rate of agreement compared to the other two categories of marital status in both countries. Furthermore, the share of divorced people agreeing with the obsoleteness of marriage was much higher than among married people. Moreover, the never married outnumbered the married quite clearly. ${ }^{15}$

Table 3: Agreement rate with marriage as an outdated institution by age groups and marital status, 1991-2017 (\%)

\begin{tabular}{|c|c|c|c|c|c|c|}
\hline & & & 1991 & 1999 & 2008 & 2017 \\
\hline \multirow{7}{*}{ Czechia } & \multirow{4}{*}{ Age groups } & $18-29$ & 11 & 19 & 43 & 28 \\
\hline & & $30-44$ & 8 & 14 & 27 & 20 \\
\hline & & $45-59$ & 5 & 10 & 18 & 13 \\
\hline & & $60+$ & 4 & 4 & 13 & 11 \\
\hline & \multirow{3}{*}{ Marital status } & Married & 5 & 9 & 14 & 7 \\
\hline & & Divorced & 11 & 22 & 27 & 22 \\
\hline & & Never married & 15 & 20 & 46 & 33 \\
\hline \multirow{7}{*}{ Slovakia } & \multirow{4}{*}{ Age groups } & $18-29$ & 7 & 16 & 21 & 36 \\
\hline & & $30-44$ & 9 & 12 & 18 & 25 \\
\hline & & $45-59$ & 6 & 9 & 13 & 17 \\
\hline & & $60+$ & 5 & 9 & 8 & 6 \\
\hline & \multirow{3}{*}{ Marital status } & Married & 7 & 7 & 12 & 15 \\
\hline & & Divorced & 11 & 28 & 24 & 26 \\
\hline & & Never married & 7 & 22 & 24 & 38 \\
\hline
\end{tabular}

Source: own calculations using EVS datasets 1991-2017 CZ and SK.

Do these opinion trajectories correspond to marriage behaviour? If we assume that responses to survey questions are verbalized attitudes that reflect (latent) values, we should find similarity between the opinions of the never-married respondents younger than 50 years

15 The shares of never married are similar - not surprisingly - to the shares of the youngest age group (18-29) in Table 3, as these respondents, the young, are usually single at that age. 
and the indicator of real marriage behaviour, which, in this case, is the total first marriage rate. In other words, we assume that with the increasing proportions over time of nevermarried respondents who agree with the statement that marriage is an outdated institution there should be a downward trend in total first marriage figures. Let us check this assumption in the following figures, starting with Czechia (see Figure 2).

Figure 2: The share of never-married respondents (aged below 50) agreeing with the statement that marriage is an outdated institution (opinion) and the total first marriage rate (TFMR) in 1991, 1999, 2008 and 2017 by gender, Czechia

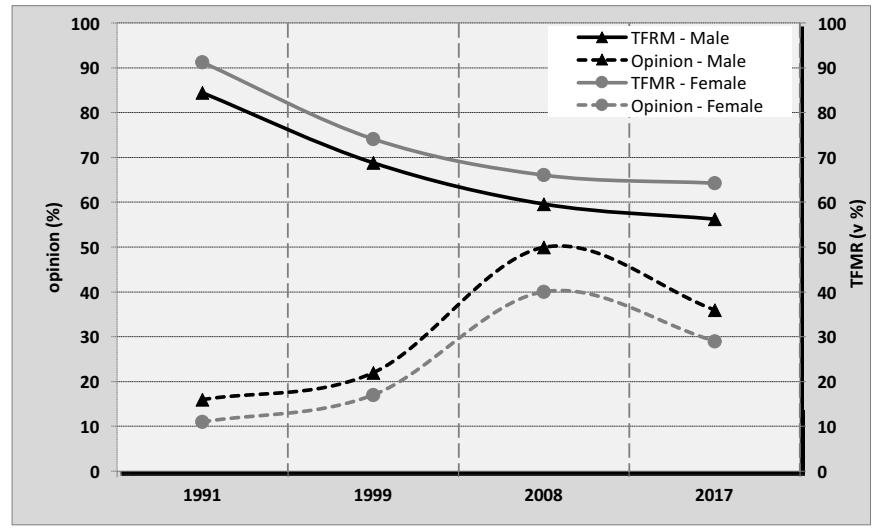

Source: Czech demographic statistics - Vývoj obyvatelstva ČR, own calculations using EVS datasets 1991-2017 CZ.

The total first marriage rate has been decreasing consistently from high proportions in 1991 $84 \%$ (male) and $91 \%$ (female) to moderate proportions in $2017-58 \%$ and $65 \%$ respectively (see the TFMR lines in Figure 2). This trend indicates that after the fall of communism, marriage has gradually lost some of its attractiveness among young people over the course of the development of modern Czech democratic society. However, part of the reason for the downward marriage trend was also economic, especially during the 1990s. Special loans for newlyweds were abolished, financial assistance for young families declined, and it became quite difficult for the young to obtain an apartment as the former state system of housing allocation shifted to an unregulated real estate market.

As far as the opinion of never-married respondents about marriage is concerned, it does not have such a straightforward pattern as the demographic indicator (TFMR). After a sharp increase from 1991 until 2008, ${ }^{16}$ it then decreased. Nevertheless, the linear estimate has an assumed upward trajectory. A comparison of demographic and attitudinal trends reveals that an increasing share of never-married respondents (noting that our sample is representative of the Czech population) thinking of marriage as an outdated institution is accompanied

16 This fact suggests that the decrease in marriages after 1990 cannot be explained solely by economic factors. 
by decreasing marriage rates in the period 1991-2008. The drop in opinions from 2008 to 2017 is associated with the end of the downward trend in marriage rates.

In Slovakia, marriage has also lost its attractiveness over time; the proportions of first marriages decreased from 81\% (male) and 87\% (female) in 1991 to 64\% and 71\% in 2017 (see TFMR lines in Figure 3). Interestingly enough, the decrease in marriages was quite sharp in 1999 (and much sharper than in Czechia) and the reason can again be partly attributed to difficult Slovak economic conditions after 1993, which made the conditions for starting a family for young couples even harder than in Czechia. ${ }^{17}$

Figure 3: The share of never-married respondents (aged below 50) agreeing with the statement that marriage is an outdated institution (opinion) and the total first marriage rate (TFMR) ${ }^{18}$ in 1991, 1999, 2008 and 2017 by gender, Slovakia

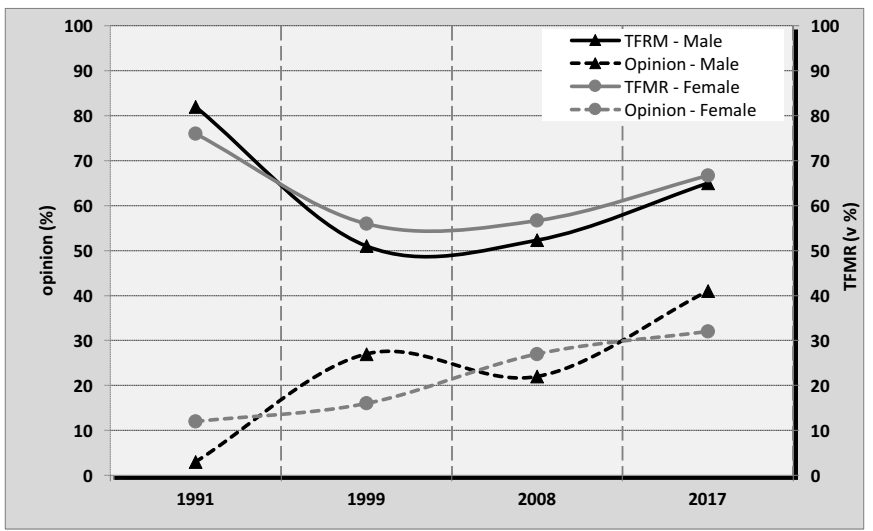

Source: Slovak demographic statistics, own calculations using EVS datasets 1991-2017 SK.

As far as the opinion trajectory is concerned, there is an almost linear increase in opinions endorsing marriage as an outdated institution among women, so here, the association between opinion and behaviour is clear-cut. Among men, there is a fluctuation in opinion on marriage as an outdated institution, but the general direction of the relationship is also as expected.

To sum up this section of our analysis, we found that the two variables measuring the attitude towards marriage and marital behaviour both act in the assumed direction. The relationship, however, was clearer among Slovak women and, to a lesser degree, among Czech women. The marital behaviour of Czech and Slovak men was also accompanied

17 The economic reasons are similar to those in Czechia mentioned earlier, but one factor must be added, the high unemployment rate in the second half of the $1990 \mathrm{~s}$, oscillating between $12 \%$ and $19 \%$.

18 TFMRs were calculated by the Slovak Statistical Office and taken from the Tabulky sobášnosti slobodných (Marriage life tables of the never married) and from www.infostat.sk 
by the opinion on marriage in contemporary society, but their opinion has fluctuated during the past 25 years. We do not venture to make any speculations on the direction of the relationship between attitudes and behaviour - what is the cause and what is the effect. The decrease in marriages over the period from 1991 to 2017 in both Czechia and Slovakia was caused by the overall change in the economic system and the system of family and social policy on the one hand and by ideational/cultural factors on the other (e.g. Katrńák 2001; Hamplová 2003; Hašková and Rabušic 2008; Kocourková and Rabušic 2006). Young Czechs and Slovaks - like the young population in Western countries in the 1960s and later - started to experiment with alternative forms of partnership, which undermined both the perception of marriage as well as related behaviour - the wedding. However, we should not forget that in 2017 about 70\% of young Czech respondents and 64\% of young Slovak respondents disagreed with the statement that marriage is an outdated institution. Even though the young still recognize marriage as an institution, they act differently. Judging from the total first marriage rates in $2017,58 \%$ of Czech men and $64 \%$ of Slovak men and $65 \%$ of Czech women and $71 \%$ of Slovak women will eventually marry by the age of 50 . The remaining proportions of the young either will postpone marriage or will not marry at all.

\section{Attitudes towards childbearing and single motherhood}

In this section, we look at the association between attitudes towards childbearing and single motherhood. Fertility has become a highly discussed topic in both the Czech and Slovak Republics. Both countries went through a period of low (i.e. fertility moderately below replacement level), very low (fertility around 1.5 children per woman), and lowest low fertility (fertility at or below 1.3 children) between 1991 and 2005, and lately, through a period of small but gradual increases by 2017 (with total fertility rate reaching 1.69 in Czechia and 1.52 in Slovakia). It is notable that although Slovakia has long been characterized by somewhat higher total fertility rates than the Czech Republic, the trend has reversed since 2005.

\section{Childbearing}

Previous research suggests that the more traditional attitudes towards women and childbearing a woman has, the more children she is likely to actually have or intend to have (cf. Kaufman 2000; Moors 2003). Attitudes towards childbearing, which we are going to use here, are measured by the following question in the EVS survey: Do you think a woman has to have children in order to be fulfilled or is this not necessary? ${ }^{19}$ Our assumption is that a high level

19 We are aware that this statement is not the best indicator of childbearing/fertility. On the other hand, though, we assume that agreement with it can indicate an attitude that is beneficial to fertility and, vice versa, the meaning of disagreement, i.e. the fact that women do not need children might reveal a less positive attitude. Unfortunately, there is no better item in the EVS questionnaire that could serve our purpose. In 1999 and 2008, a question concerning the statement $A$ man has to have children in order to be fulfilled was added but it was abandoned in 2017. 
of agreement with this statement indicates a pro-population climate, while a low level points to a liberal environment, suggesting that life without children can be meaningful for women.

The following analyses are run separately for men and women, by age groups and marital status. We start with the distribution of answers in the total population and by gender (see Figure 4).

Figure 4: Agreement with the necessity for a woman to have children in Czechia and Slovakia, 1991-2017 (\%)

\section{CZ}

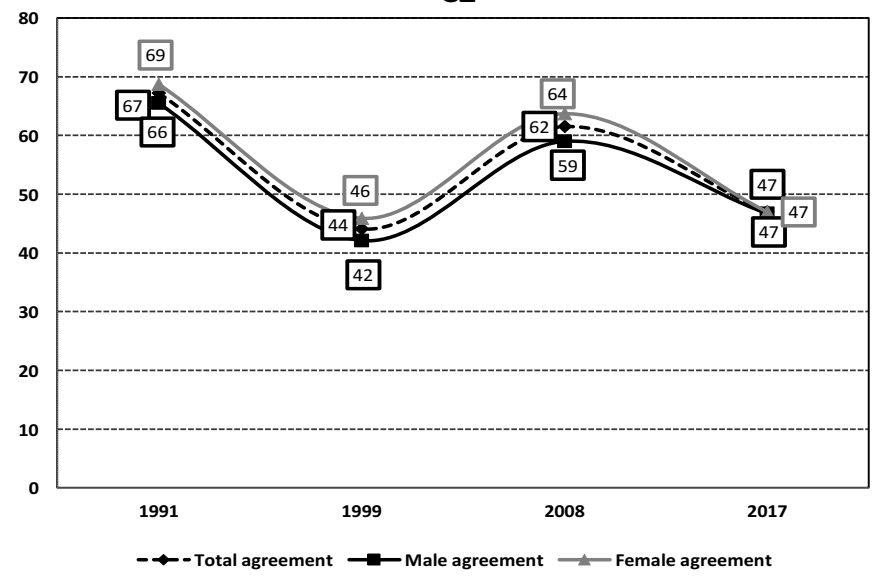

SK

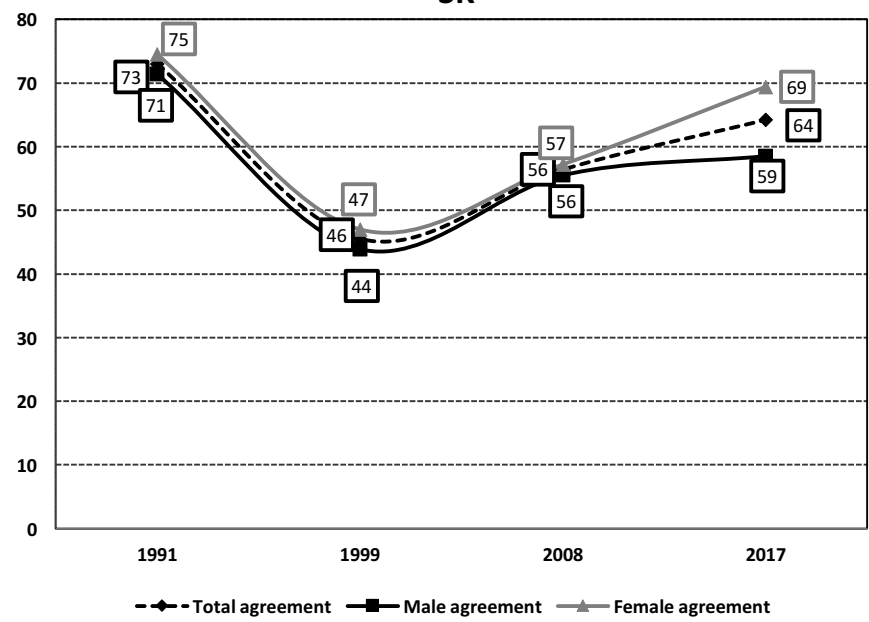

Source: own calculations using EVS datasets 1991-2017 CZ and SK.

As is evident, the trends among the total samples were similar in both countries from 1991 to 2008 , starting with $67 \%$ in Czechia and $73 \%$ in Slovakia in 1991, dropping to $44 \%$ and $46 \%$ 
respectively in 1999 and increasing to $62 \%$ and $56 \%$ by 2008 . Then, the paths diverged, ending up at $47 \%$ in Czechia and $64 \%$ in Slovakia. This difference is quite pronounced and it implies that about two thirds of Slovak respondents, compared to only about half of Czechs, nowadays regard children as an element in a woman's life without which life would not be satisfying. In 2017, another difference is visible, namely between Slovak male and female opinions. While in previous years the difference was negligible, it has become significant both in statistical and factual terms in 2017, when women outnumbered men in their agreement with the statement (69\% vs. 59\%). We do not see such a trend among Czech respondents men and women had quite similar attitudes in this respect in all the studied years. Why has Slovakia, especially Slovak women, started to become more traditional in 2017 when various socio-economic indicators of modernization show that Slovakia (and Czechia as well) has undergone a huge transformation since the 1990s that placed the country among the family of highly developed societies? The explanation may be related to the period of economic crisis that hit Slovakia after 2008. The unemployment rate oscillated between $12 \%$ and $14 \%$ from 2009 to 2015 (it was only 5\%-7\% in Czechia) ${ }^{20}$ and it decreased to 8\% in 2017 (only $3 \%$ in Czechia). Further, $18 \%$ to $21 \%$ of the Slovak population was at risk of poverty in the period between 2008 and 2016 (12-14\% in Czechia). This crisis may have prompted people (especially women) to turn their attention again to the private sphere and put more emphasis on how they evaluate children and the family.

As far as the association of attitude and age is concerned, the data show (see Table 4) the expected age gradient: younger age groups consistently have the lowest level of agreement and conversely, older groups have the highest in both countries regardless of the year of measurement.

The distribution of answers by marital status is also illustrated in Table 4. The results are in line with the theory of individualization and modernization (more on this in Fučík et al. 2019) and are the same for both countries. Single (never-married) respondents agree least with the necessity for women to have children, whereas the married share traditional views on childbearing, having the highest agreement rates. Those who experienced marriage followed by divorce have a lower agreement rate than the married, but not as low as nevermarried respondents.

To find out whether there is an association between demographic and attitudinal data, we limit our analysis only to female respondents aged 18-49 as we deal with fertility and demographic indicators on fertility exclusively reported for this group in the population. Firstly, the distribution of answers to the question on the necessity for a woman to have children is shown in Figure 5.

20 Moreover, unemployment among women is usually higher than among men. 
Table 4: Agreement rate with the necessity for a woman to have children by age groups and marital status in Czechia and Slovakia, 1991-2017 (\%)

\begin{tabular}{|c|c|c|c|c|c|c|}
\hline & & & 1991 & 1999 & 2008 & 2017 \\
\hline \multirow{7}{*}{ Czechia } & \multirow{4}{*}{ Age groups } & $18-29$ & 57 & 32 & 52 & 38 \\
\hline & & $30-44$ & 66 & 38 & 58 & 39 \\
\hline & & $45-59$ & 73 & 50 & 65 & 47 \\
\hline & & $60+$ & 73 & 56 & 69 & 59 \\
\hline & \multirow{3}{*}{ Marital status } & Married & 68 & 45 & 66 & 52 \\
\hline & & Divorced & 62 & 42 & 61 & 47 \\
\hline & & Never married & 51 & 34 & 50 & 34 \\
\hline \multirow{7}{*}{ Slovakia } & \multirow{4}{*}{ Age groups } & $18-29$ & 67 & 37 & 49 & 51 \\
\hline & & $30-44$ & 69 & 47 & 53 & 63 \\
\hline & & $45-59$ & 75 & 42 & 60 & 70 \\
\hline & & $60+$ & 83 & 58 & 66 & 73 \\
\hline & \multirow{3}{*}{ Marital status } & Married & 74 & 48 & 63 & 74 \\
\hline & & Divorced & 68 & 29 & 46 & 61 \\
\hline & & Never married & 64 & 34 & 39 & 42 \\
\hline
\end{tabular}

Source: own calculations using EVS datasets 1991-2017 CZ and SK.

Figure 5: A woman needs children to be fulfilled (\% agreement). Female respondents aged 18-49 in Czechia and Slovakia, 1991-2017

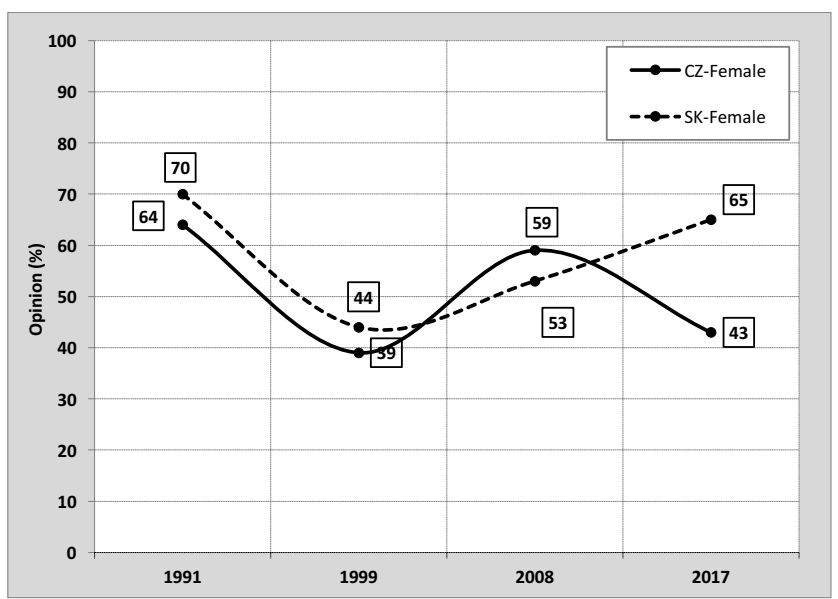

Source: own calculations using EVS datasets 1991-2017 CZ and SK.

The curves are similar, naturally, to the ones for women in Figure 4. We see that in 1991, in both countries, female respondents of reproductive age were still under the influence of the so-called old (communist) demographic regime that supported high fertility; therefore, 
the level of agreement was relatively high. Sixty-four percent in Czechia and 70\% in Slovakia declared that a woman must have children in order to be fulfilled in life. By 1999, the agreement level significantly declined (by about 25\% in both countries), which can be understood as a consequence of the overall modernization of both societies and, also as an indicator of the process related to the Second Demographic Transition. Between 1999 and 2008, however, the attitude towards childbearing children changed again and the share of affirmative answers increased (surprisingly, more in Czechia than in Slovakia), and almost approached the level found in 1991 in the Czech Republic. It seems that something interesting happened in Czechia in 2008 from the point of view of the population climate. In Figure 2, we see that there is a substantial rise in the number of never-married single respondents (both men and women) who agree that marriage is an outdated institution, and the share of female respondents who think that women need children for life fulfilment increased as well. ${ }^{21}$ We do not yet have an explanation; it will require further contextual exploration and data.

After 2008, the situation changed again and by 2017, the pattern of the "wavy-line" trajectory was confirmed in Czechia: the agreement level decreased and almost approached the values recorded in 1999. Note also that the attitude towards marriage changed (see Figure 1) - the share of female respondents agreeing with the statement that marriage is an outdated institution decreased from $22 \%$ to $14 \%$. Thus, according to the survey data, it seems that nowadays, the young Czech population (never married and of fertile age) does not regard marriage as an outdated institution (only about one third holds such an attitude) and does not think that women must have children for a meaningful life (only one third of female respondents). In Slovakia, there has been a continued increase in the intensity of agreement (from 45\% in 1999 to $65 \%$ in 2017), which means that nowadays, more than two thirds of all Slovak women of reproductive age are convinced that women do need children for fulfilment in life. On the other hand, only one third of single women regard marriage as obsolete (see Figure 1). ${ }^{22}$

We will check now whether such an attitude - as an indicator of fertility climate is accompanied by fertility behaviour in practice. Again, as with marriage, we use fertility data (i.e. total fertility rate) only for the years in which the EVS survey was carried out. As shown in Figures $6 \mathrm{a}$ and $6 \mathrm{~b}$, the association between attitude and behaviour is present to some extent in both countries, more in Slovakia than in Czechia, however.

In Czechia, the curve of fertility behaviour clearly copies the attitudinal curve between 1991 and 2008. From then on, the attitude towards the necessity of having children rapidly decreased, but the total fertility rate kept increasing, indicating that attitude and behaviour diverged, as is evident from the linear estimates of the two trends. In Slovakia, there is a better

21 The shape of both the male and female curves is similar in both countries with a somewhat higher share of agreement with the statement among women. However, the difference does not exceed $5 \%$ from 1991-2008 and it is within the margin of sampling error. There is one exception - in 2017, the difference reached 11 percentage points in Czechia (44\% among women and 33\% among men), which is statistically significant (the difference in Slovakia was only 4\%).

22 A tentative explanation might be found in footnote 10 and the corresponding text. 
match between female attitudes towards childbearing children and fertility behaviour than in Czechia (see the linear estimate lines in Figure 6b).

Figure 6a: Agreement with the statement on a woman's necessity to have children (female respondents aged 18-49) and TFR, 1991-2017, Czechia

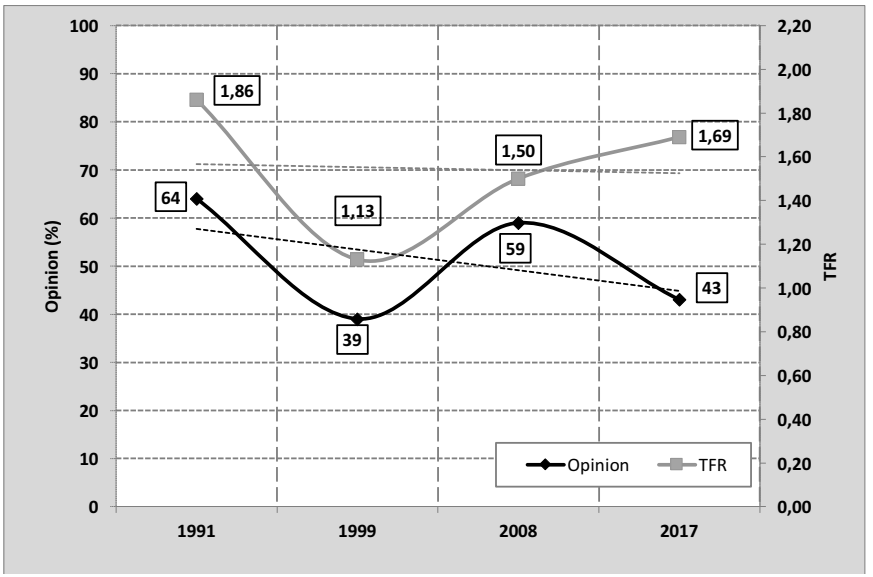

Note: Fine lines are the linear estimates of the trends.

Source: Demographic statistics CZ, own calculations using EVS datasets 1991-2017 CZ.

Figure 6b: Agreement with the statement on a woman's necessity to have children (female respondents aged 18-49) and TFR, 1991-2017, Slovakia

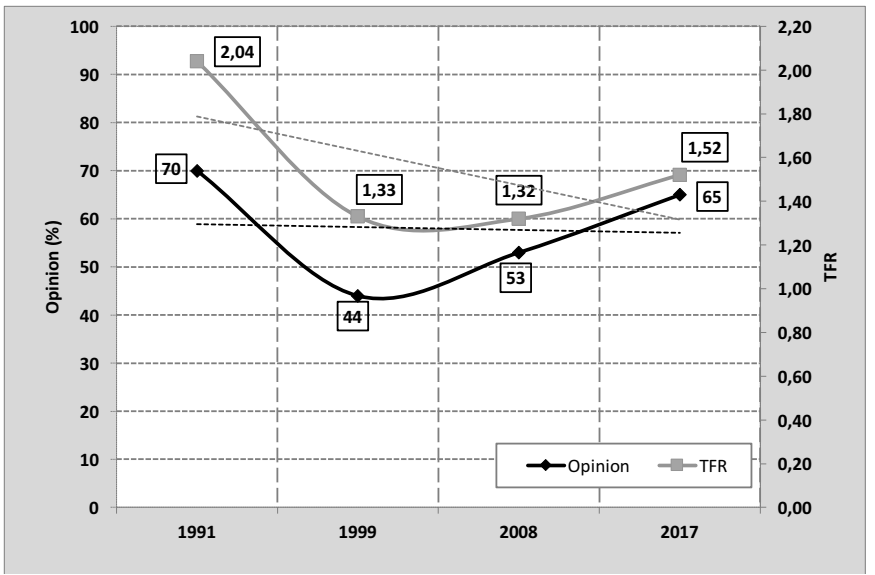

Note: Fine lines are the linear estimates of the trends.

Source: Demographic statistics SK, own calculations using EVS datasets 1991-2017 SK. 


\section{Single motherhood}

Parenting outside of marriage is an indicator of destandardization because marriage is no longer a key prerequisite for the transition to parenthood. The link between marriage, giving birth and childrearing has been strong in the history of Czech and Slovak societies, and thus, the proportion of children born out-of-wedlock has been low, fluctuating around five per cent during the communist demographic regime (1950-1990). Since 1989, a process of destandardization of the life course ${ }^{23}$ has been occurring in both countries, especially in the case of the transition to marriage and parenthood. The sharp increase in extra-marital fertility is related to the social and value transformation of Central and Eastern European countries that took place after 1990.The situation changed in the 1990s and the formerly low figures started to climb sharply, reaching 49\% and 40\% in Czechia and Slovakia in 2017 (see Figure 7).

Figure 7: The share of births out of wedlock in CZ and SK, 1991-2017 (in \%)

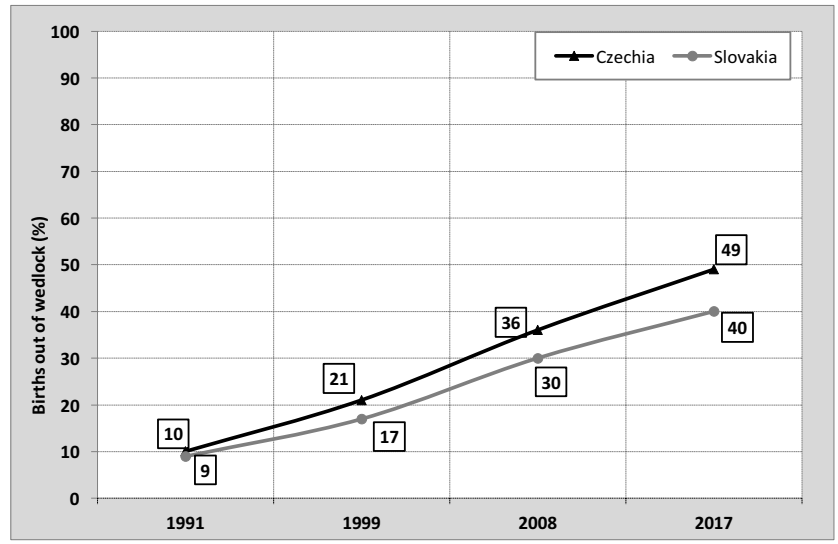

Source: Demographic statistics CZ and SK.

The issue of out-of-wedlock births is not a new phenomenon because since the 1970s, when the trend towards extramarital fertility rose in Nordic countries and gradually in other parts of Europe as well, extramarital fertility has become widespread across modern societies.

With the spread of extra-marital fertility in the population, the characteristics of unmarried mothers also changed; during the early 1990s, unmarried mothers in the Czech population were either very young or divorced - they were mainly women without a partner or women from lower social strata. Later, this group of mothers ceased to be so uniform and has become much more diverse (Štípková 2013; Zeman 2007). Nowadays, it includes single mothers living with a partner, divorced mothers with a new partner, abandoned

23 Destandardization is a change in the rate of life transitions, a greater variance in their duration and a lesser attachment to chronological age (Brückner and Mayer 2005). 
mothers, mothers who have decided to become single mothers without a partner or mothers living in a homosexual relationship.

Slovakia also represented the typical characteristics of the "marriage-fertility model" until 1990 , when almost $95 \%$ of children were born in marriage. Extra-marital fertility reached almost $18 \%$ by the end of the 1990s, close to the Czech rates of extra-marital fertility. After 2000, non-marital birth rates have continued to increase, reaching relatively high levels in $2017 .{ }^{24}$

The simple analysis of demographic statistics is not enough to describe the phenomenon of non-marital fertility or to provide an answer to the question of why some women or couples decide to have children out of wedlock. Scholars have not reached a clear consensus on the reasons for extra-marital fertility: whether it is the free choice of individuals or a result of some difficulties (economic, partnership mating etc.). Sometimes, motherhood outside marriage is voluntary; sometimes it is involuntary. Our explanation for the rise in the share of single mothers in both Czech and Slovak societies in the 1990s relies on Second Demographic Transition (SDT) theory (van de Kaa 1987; Lesthaeghe 2010). SDT theory emphasizes the changes in the value orientations of the current generations of mothers, for whom marriage is not a necessary life phase (they might consider it to be an outdated institution) and single motherhood is a consciously chosen life strategy.

The following analysis seeks to reveal how value orientation towards single motherhood has changed and whether the value change is reflected in the demographic data on out-ofwedlock fertility. The EVS indicator we used measures liberal attitudes towards children born out of wedlock. The EVS question is phrased as follows: "If a woman wants to have a child, but she wants to be a single parent and live without a man, do you approve or disapprove?" EVS data show that there was increasing acceptance of single motherhood in both Czechia and Slovakia between 1991 and 2017 - from 28.4\% to 50.3\% in Czechia and from $25.7 \%$ to $38.3 \%$ in Slovakia. As expected, a lower level of agreement was found among married respondents and in contrast, there existed higher agreement among never-married respondents. In addition, the younger a person was, the higher the support of agreement with single motherhood. ${ }^{25}$

In order to better describe the relationship between attitudes and demographic behaviour, we operate now only with women in their reproductive years (18-49). Figure 8 shows the general increasing share of Czech and Slovak women aged 18-49 who approve of single motherhood: from about one third in 1991 to $63 \%$ in Czechia and $52 \%$ in Slovakia in 2017 (with a small drop in 2008). Nowadays, more than half of Czech and Slovak women of reproductive age approve of single motherhood. ${ }^{26}$

24 The contemporary intensity of out of wedlock births is still lower in both Czechia and Slovakia than it is in some European countries (e.g. Iceland, France, Norway and Sweden).

25 Due to space constraints, the results for the whole population and by sex, age groups and marital status are not shown.

26 In the Czech Republic, the trend for male respondents aged 18-49 accompanied the female trend between 1991 and 2008, but it went down by 2017 (reaching 52.5\%). In Slovakia, the trend among men mirrored that of women between 1991 and 2017, but the rise in the agreement rate was flatter (37.7\%). Slovak as well as Czech men thus approve of single motherhood. 
Figure 8: The share of agreement with single motherhood for women of reproductive age (18-49) in CZ and SK, 1991-2017 (in \%)

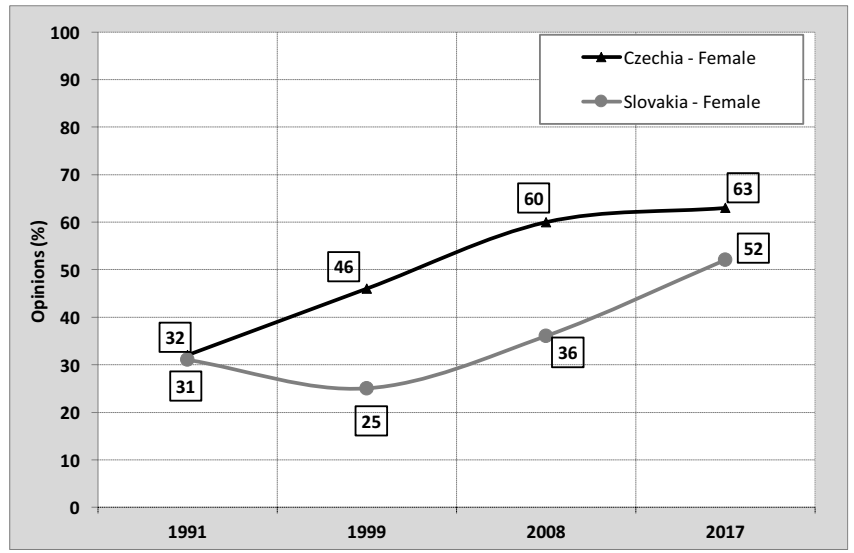

Source: own calculations using EVS datasets 1991-2017 CZ and SK.

Figures $9 \mathrm{a}$ and $9 \mathrm{~b}$ offer a portrait of the association between attitudes towards single motherhood and out-of-wedlock childbirth rates. In both countries, there is very close correspondence between attitude and behaviour.

Figure 9a: The share of agreement with single motherhood in the female population aged 18-49 and the proportion of children born out of wedlock in Czechia, 1991-2017 (in \%)

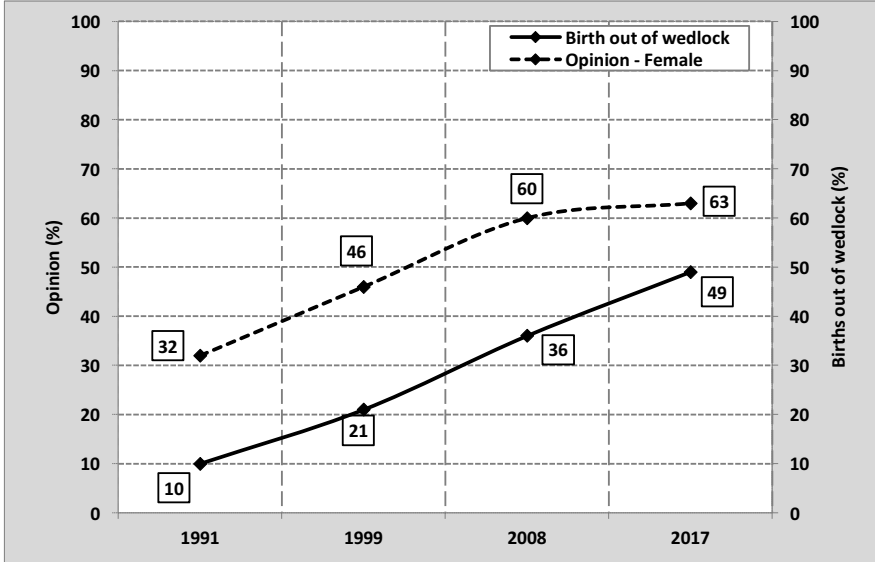

Source: Demographic statistics CZ, own calculations using EVS datasets 1991-2017 CZ. 
Figure 9b: The share of agreement with single motherhood in the female population aged 18-49 and the proportion of children born out of wedlock in Slovakia, 1991-2017 (in \%)

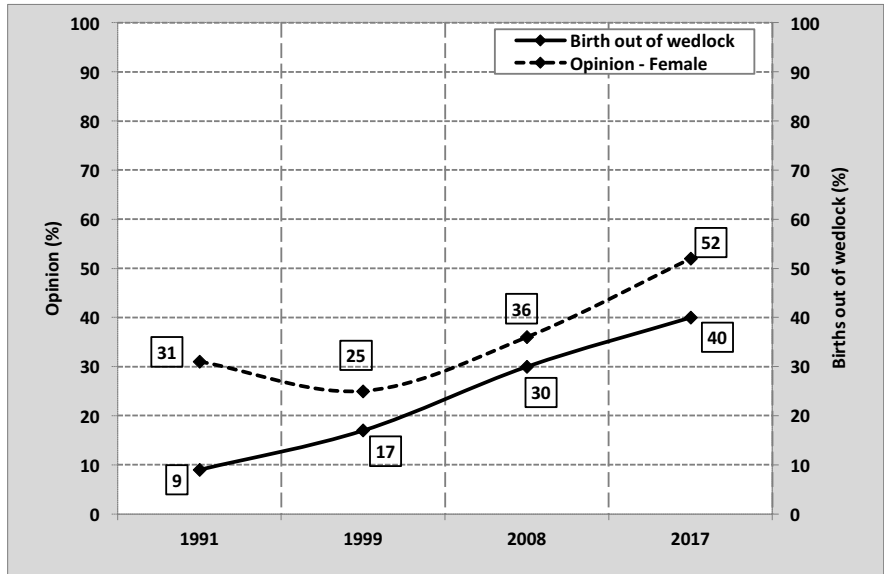

Source: Demographic statistics SK, own calculations using EVS datasets 1991-2017 SK.

As in our previous analysis, we cannot state whether a positive attitude towards out-ofwedlock birth has triggered a higher number of births among unwed mothers, or vice versa, whether increased birth rates among unwed mothers has led to the mental rationalization (approval) of such behaviour. More women approve of out-of-wedlock births than actually give birth outside of marriage - the difference between approval (survey data) and real behaviour (demographic statistics) is $12 \%$ and $14 \%$ in Czechia and Slovakia, respectively.

\section{Conclusions}

In this article, we aimed to find out whether values concerning marriage, childbearing and single motherhood are linked to real demographic behaviour, namely, to total first marriage rates, total fertility rates and out-of-wedlock birth rates. We used two sets of data series: (i) from the longitudinal European Values Study, which regularly measures the items that we used as indicators of the above-mentioned attitudes and (ii) data from Czech and Slovak vital statistics to illustrate real-world behaviour.

Our analysis has shown that the correspondence between attitudinal survey-microdata and aggregated (statistical) macro data is quite considerable and that there is a link/ association between attitudes and behaviours. We found that the trends in both sets of data do not go against each other and they are, statistically speaking, positively associated. Saying so, however, we are far from the assertion that this statistical relationship is a causal one. Nor we do dare to clearly say which variable, demographic or attitudinal, is dependent and which is independent. Nevertheless, our survey data series covering the period from 1991 to 2017 show that in Czechia and Slovakia, there has been a change in values (operationalized by attitudinal questionnaire items) concerning marriage, childbearing and single motherhood 
and that the change occurred hand-in-hand with modernization of the former communist countries that were economically "backward" and politically totalitarian. Viewed from the perspective of the Second Demographic Transition, the value change was in concordance with the theory of the SDT. Demographic data series covering the same period show that in both Czechia and Slovakia trends in nuptiality, childbearing and extramarital fertility correspond to the trends that are predicted by the $S D T$.

The question concerning the mutual association between values and behaviour and their causal relationship remains difficult to answer. However, we can formulate this question in a different way and ask: would it be possible to reconstruct accurate demographic trends in a certain society by knowing its level of modernization and the trajectory of the attitudes that we have used in our analysis? We argue that if we know that a considerable segment of the population (especially among the young) regards marriage as an obsolete institution, that a large share of the population thinks women do not need children to lead a meaningful life and that a large proportion of the population agrees that women could have children as single mothers, then we can predict that in such a society, nuptiality should be rather low, along with fertility (at least below replacement level), and the out-of-wedlock birth rate should be relatively high. ${ }^{27}$

We are inclined to believe that the changes in personal values and attitudes concerning marriage and childbearing issues do play an important role in the explanation of fertility decline or postponement and the (in)stability of marital relationships and the development of new family forms. Nevertheless, the remark by Peter Uhlenberg that "the question of the 'rightful place' of values is still open" (Uhlenberg 2000: 400), remains highly relevant.

As far as the comparison between Czechia and Slovakia, we can argue that the two countries share relatively similar value trends measuring attitudes towards marriage, childbearing and single motherhood, as well as in demographic trends. Some of the Slovak trends show lower intensity, however, and a certain time lag, likely due to the slower development of post-modernization in Inglehart's (1997) and Inglehart and Welzel's sense (2005).$^{28}$ Nevertheless, both countries more or less mirror the (post)modernization tendencies observed in the recent past and that can be observed now in the West.

27 An interesting question would be whether a demographer knowing the relevant demographic trends would be able to approximate the relevant attitudinal trends.

28 "Post-modernization" in Inglehart and Welzel's (2005) sense implies socio-economic modernization, accompanied by increasing liberty aspirations, and enforcement and development of democratic institutions. Altogether these bring a shift towards self-expression values and broadening of human choice. 


\section{References}

BECKER, Gary S. 1981. A Treatise on the Family. Enl. ed. Cambridge, MA: Harvard University Press. BRÜCKNER, Hannah and Karl Urlich MAYER. 2005. "De-standardization of the Life Course: What It Might Mean? And If It Means Anything, Whether It Actually Took Place?" Advances in Life Course Research 9(1): 27-53.

CLELAND, John. 1985. "Marital Fertility Decline in Developing Countries: Theories and the Evidence." Pp. 223-252 in Reproductive Change in Developing Countries: Insights from the World Fertility Survey, edited by John CLELAND and John HOBCRAFT. London: Oxford University Press.

DEYL, Zdeněk. 1985. Sociální vývoj Československa 1918-1938. Prague: Academia.

EASTERLIN, Richard A. 1980. Birth and Fortune: The Impact of Numbers on Personal Welfare. New York: Basic Books.

FUČÍK, Petr, Beatrice-Elena CHROMKOVÁ MANEA, and Ladislav RABUŠIC. In Press. "K problému de-instituzionalizace manželství [On the De-institutionalization of Marriage]." In Oddělení, nebo spolu? (Česko a Slovensko optikou vývoje hodnot po roce 1991) [“Living apart together"? - Czechia and Slovakia through the lense of value development after 1991], edited by Ladislav RABUŠIC, Zuzana KUSÁ, Beatrice-Elena CHROMKOVÁ MANEA, and Katarina STRAPCOVÁ. Bratislava: Slovart.

GOLDSCHEIDER, Calvin. 1999. "Religious Values, Dependencies, and Fertility: Evidence and Implications from Israel.” Pp. 310-330 in Dynamics of Values in Fertility Change, edited by Richard LEETE. Oxford: Oxford University Press.

HAMPLOVÁ, Dana. 2003. Vstup do manželství a nesezdaného soužití v České republice po roce 1989 $v$ souvislosti se vzdèláním [Marriage and Cohabitation Entry by the Level of Education, Czech Republic after 1989]. Prague: SOÚ AV ČR.

HAŠKOVÁ, Hana and Ladislav RABUŠIC. 2008. "K nízké sňatečnosti v české republice [On Low Marriage Rate in the Czech Republic].” Sociálni studia/Social Studies 5(2): 9-32.

INGLEHART, Ronald and Christian WELZEL. 2005. Modernization, Cultural Change, and Democracy: The Human Development Sequence. Cambridge: Cambridge University Press.

INGLEHART, Ronald. 1977. The Silent Revolution. Princeton, NJ: Princeton University Press.

INGLEHART, Ronald. 1997. Modernization and Postmodernization: Cultural, Economic and Political Change in 43 Societies. Princeton, NJ: Princeton University Press.

KATRŇÁK, Tomáš. 2001. "Strukturální příčiny poklesu sňatečnosti a nárůstu svobodných v České republice v průběhu devadesátých let [Structural Causes of the Decline in the Number of Marriages and the Increase in the Number of Single Women and Men in the Czech Republic in the 1990s]." Sociologický časopis/Czech Sociological Review 37(2): 225-240.

KAUFMAN, Gayle. 2000. "Do Gender Roles and Attitudes Matter? Family Formation and Dissolution Among Traditional and Egalitarian Men and Women." Journal of Family Issues 21(1): 128-144.

KINGSLEY, Davis. 1963. "The Theory of Change and Response in Modern Demographic History." Population Index 29(4): 345-366.

KOCOURKOVÁ, Jiřina and Ladislav RABUŠIC. 2006. Sn̆atek a rodina: zájem soukromý nebo veřejný?: Proměny reprodukčního chováni a možnosti rodinné politiky z hlediska postojů české veřejnosti [Marriage and Family: Private or Public Interest?]. Prague: UK.

LESTHAEGHE, Ron. 1983. "A Century of Demographic and Cultural Change in Western Europe." Population and Development Review 9(3): 411-435.

LESTHAEGHE, Ron. 1995. "The Second Demographic Transition in Western Countries: An Interpretation." Pp. 17-62 in Gender and Family Change in Industrialized Countries, edited by Karen Oppenheim MASON and An-Magritt JENSEN. Oxford: Clarendon Press. 
LESTHAEGHE, Ron. 2010. "The Unfolding Story of Second Demographic Transition.” Population and Development Review 36(2): 211-251.

MCDONALD, Peter. 2006. "Low Fertility and the State: The Efficacy of Policy." Population and Development Review 32(3): 485-510.

MOORS, Guy. 2003. "Estimating the Reciprocal Effect of Gender Role Attitudes and Family Formation: A Log-linear Path Model with Latent Variables.” European Journal of Population 19(2): 199-221.

RETHERFORD, Robert D., Naohiro OQAWA, and Satomi SAKAMOTO. 1999. "Values and Fertility Change in Japan." Pp. 121-147 in Dynamics of Values in Fertility Change, edited by Richard LEETE. Oxford: Oxford University Press.

RINDFUSS, Ronald R., Karin L. BREWSTER, and Andrew L. KAVEE. 1999. "Women, Work, and Children: Behavioural and Ideational Change in the United States." Pp. 148-178 in Dynamics of Values in Fertility Change, edited by Richard LEETE. Oxford: Oxford University Press.

SOBOTKA, Tomáš, Anna ŠŤASTNÁ, Kryštof ZEMAN, Dana HAMPLOVÁ, and Vladimira KANTOROVÁ. 2008. "Czech Republic: A Rapid Transformation of Fertility and Family Behaviour after the Collapse of State Socialism." Demographic Research, Special Collection 7, 19 (Article 14): 403-454.

SOBOTKA, Tomáš, Kryštof ZEMAN, and Vladimira KANTOROVÁ. 2003. "Demographic Shifts in the Czech Republic After 1989: A Second Demographic Transition View." European Journal of Population 19(3): 249-277.

SOBOTKA, Tomáš. 2008. "The Diverse Faces of the Second Demographic Transition in Europe." Demographic Research 19 (Article 8): 171-224.

ŠTÍPKOVÁ, Martrina 2013. "Declining Health Disadvantage of Non-marital Children: Explanation of the Trend in the Czech Republic 1990-2010." Demographic Research 29: 663-706.

SURKYN, Johan and Ron LESTHAEGHE. 2004. "Value Orientations and the Second Demographic Transition (SDT) in Northern, Western and Southern Europe: An Update.” Demographic Research Special Collection 3: 45-86.

THORNTON, Arland and Dimiter PHILIPOV. 2009. "Sweeping Changes in Marriage, Cohabitation and Childbearing in Central and Eastern Europe: New Insights from the Developmental Idealism Framework." European Journal of Population/Revue européenne de Démographie 25(2): 123-156.

UHLENBERG, Peter. 2000. "Review of Dynamics of Values in Fertility Change." Population and Development Review 26(2): 399-401.

VAN DE KAA, Dirk J. 2001. "Postmodern Fertility Preferences: From Changing Value Orientation to New Behavior." Pp. 290-332 in Global Fertility Transition, edited by Rodolfo A. BULATAO and John B. CASTERLINE. New York: Population Council.

VAN DE KAA, Dirk. J. 1987. “Europe's Second Demographic Transition.” Population Bulletin 42 (1), Washington, The Population Reference Bureau.

ZEMAN, Kryštof. 2007. "Nemanželská plodnost - demografický přehled [Out-of-wedlock Childbearing - A Demographic Overview]." Pp. 17-28 in Déti na psi knižku: Mimomanželská plodnost v ČR [Out-of-wedlock Childbearing in the Czech Republic], edited by Dana HAMPLOVÁ, Jana CHALOUPKOVÁ, Eva SOUKUPOVÁ, Petr SUNEGA, and Kryštof ZEMAN. Prague: Institute of Sociology.

\section{Authors}

Beatrice-Elena Chromková Manea is a researcher at the Office for Population Studies belonging to the Faculty of Social Studies, Masaryk University in Brno. Her research interests include fertility behaviour and intentions, preferences for family and work, wellbeing and health. She is the co-editor and co-author of the monograph Rodičovské dráhy: 
Dvacet let vývoje české porodnosti v sociologické perspektivě (Parental Pathways: Twenty Years of Czech Fertility Developments in a Sociological Perspective). She has published several papers analyzing fertility behaviour and intentions.

Contact: manea@fss.muni.cz

Ladislav Rabušic is the head of the Office for Population Studies and a professor at the Faculty of Social Studies, Masaryk University in Brno. He mainly focuses on population studies and value changes. He is the author of dozens of articles and a number of chapters in books published both in the Czech Republic and abroad. He is the Czech representative in the Council of Program Directors of the European Comparative Research Consortium European Values Study.

Contact: rabu@fss.muni.cz 